Article

\title{
Evaluation of Biochar and Compost Mixes as Substitutes to a Commercial Propagation Mix
}

\author{
Lan Huang ${ }^{1}$, Ping $\mathrm{Yu}^{2}$ and Mengmeng $\mathrm{Gu}{ }^{3, *}$ \\ 1 Institute of Urban Agriculture, Chinese Academy of Agricultural Sciences, Chengdu 610000, China; \\ huanglan_92@163.com \\ 2 Department of Horticultural Sciences, Texas A\&M University, College Station, TX 77843, USA; \\ yuping520@tamu.edu \\ 3 Department of Horticultural Sciences, Texas A\&M AgriLife Extension Service, College Station, \\ TX 77843, USA \\ * Correspondence: mgu@tamu.edu; Tel.: +1-979-845-8567
}

Received: 26 September 2019; Accepted: 14 October 2019; Published: 17 October 2019

\begin{abstract}
The effects of biochar (BC) on seed propagation depend on the type of BC, BC incorporation rate, base substrate, and plant seed species. Limited research tested BC-compost mixes for seed propagation. High percentages ( $70 \%$ or $80 \%$, by volume) of BC with vermicompost (VC) or chicken manure compost (CM) were evaluated to substitute a commercial propagation mix (control) in three experiments. Seeds, including basil, coleus, edamame, marigold, okra, petunia, radish, salvia, tomato, vinca, and zinnia in Experiments 1 and 2 had similar or higher emergence percentages (EPs) and emergence indexes (EIs) in both BC:VC mixes, while celosia, cowpea, corn, and pumpkin had lower EPs or EIs in either 8BC:2VC or 7BC:3VC mixes compared to the control. Seedling fresh weights in both $\mathrm{BC}: \mathrm{VC}$ mixes were similar to the control except for vinca, pumpkin, marigold, and salvia. The BC:VC mixes had no negative effects on plant dry weights at 7 weeks after transplanting. In Experiment 3, BC:CM mixes suppressed the seed germination or seedling growth of coleus, corn, cowpea, marigold, petunia, pumpkin, radish, salvia, vinca, watermelon, and zinnia due to high $\mathrm{pH}$ and CM's high electrical conductivity. Therefore, 7BC:3VC and 8BC:2VC can be used as seed propagation mix, while 7BC:3CM and 8BC:2CM are not recommended.
\end{abstract}

Keywords: biochar; germination; propagation mix; vermicompost; chicken manure compost

\section{Introduction}

Seed germination refers to the process, which starts with the seed imbibition of water and terminates with the emergence of radicle [1]. In order for the seeds to germinate, it is important for the seeds to be in touch with adequate propagation substrates to provide optimal conditions. Generally, commercial propagation mix includes different percentages of peat moss, vermiculite, and perlite to provide appropriate physical properties to hold water and provide air for seeds to grow. However, the harvest of peat moss has caused ecological concerns about damage to the peatlands and greenhouse gas emissions [2,3], and the cost of the commonly used germination mix components was continuously increasing [4,5]. All these factors have led to the necessity to find alternative propagation mix for seed germination.

Biochar (BC) is a carbonaceous material obtained from the pyrolysis of biomass, including plant-based materials, such as wood, grasses, or crop residues [6,7], and animal-based materials, such as crab shell [8] or manure [9-11]. Biochar has the potential to reduce greenhouse gas emissions [12], sequester environmental contaminants [13] and be used as a valuable substrate component for plant production [14-18]. Biochar is regarded as a sustainable product, which turns agriculture waste products into valuable materials. As the byproduct of the pyrolysis process, the use of $\mathrm{BC}$ in plant 
production adds extra value to the bioenergy process [19]. Research has shown the potential of BC to be used in seed propagation substrate for agricultural production [20]. It was shown that coconut shell $\mathrm{BC}(5 \%, 10 \%, 20 \%$, or $40 \%$, by volume) could be mixed with an adapted cornell seed germination mix and did not affect final germination percentages [21]. Additionally, the rate of BC incorporation, base substrate, and the plant species all have effects on the final seed germination and seedling growth. Prasad et al. [22] showed tomato (Solanum lycopersicum) seed germination and plant growth were higher in peat mixes with $10 \%$ woodchips BC than those in mixes with $50 \%$ BC. Similarly, Margenot et al. [23] evaluated the softwood BC substitution for peat in a 70:30 (v/v) peat:perlite mixture on marigold (Tagetes erecta) seed germination and seedling growth. They concluded that mixes with high BC substitution rate $(50 \%, 60 \%$, or $70 \%$, by vol) had lower germinations than the mixes with low $\mathrm{BC}$ rates $(0,10 \%, 20 \%, 30 \%$, or $40 \%$, by vol) with all substrate pHs adjusted to 5.8 . Compared to the $70: 30(\mathrm{v} / \mathrm{v})$ peat:perlite mixture, mixes with $10 \%$ or $70 \% \mathrm{BC}$ led to lower plant height while mixes with $20 \%, 30 \%, 40 \%, 50 \%$, or $60 \%$ BC had no effect. Fan et al. [24] also pointed out that the lower germination rate and plant height of water spinach (Ipomoea aquatica Forsk) were found in substrates with more wheat straw BC, and that the seed germination rate and plant height in substrates with $16 \%$ (by volume) $\mathrm{BC}$ with $0.8 \mathrm{~g} \mathrm{~L}^{-1}$ super absorbent polymer were higher than the substrates without super absorbent polymer, indicating that both the BC incorporation rate and base substrate affect seed germination and seedling establishment. Gascó et al. [25] showed that five different seeds, including lentil (Lens culinaris Medikus cv. Pardina), cress (Lepidium sativum), cucumber (Cucumis sativus cv. Wisconsin SMR-58), tomato (cv. Alicante), and lettuce (Lactuca sativa cv. Great Lakes) seeds had different responses to three different $\mathrm{BC}$ mixes prepared from wood, paper sludge plus wheat husks, and sewage sludge. Therefore, the impact of substrates amended with $B C$ on seed propagation and plant growth had been variable. Mixes with high percentages of $B C$ tend to have less positive effects on seed germination and seeding growth compared to those with low percentages.

However, the hardwood BC was suitable to be used as container substrates to grow plants. Research has shown positive results for using a high rate ( $80 \%$, by volume) of the hardwood BC with composts when growing tomato and basil (Ocimun basilicum) in containers [26,27]. It may be suitable as a propagation mix at a high rate, if incorporated with substrate components with fine textures, such as composts.

Composts are valuable alternative components for soilless substrates. Composting and vermicomposting are generally considered as environmentally-friendly and sustainable management processes to recycle plant or animal organic wastes [28]. Vermicompost (VC) is the end product of using earthworms to degrade organic wastes $[29,30]$, which has fine particulate structures and a lot of nutrients $[31,32]$. Biochar mixes with VC may increase nutrient retention and have a positive impact on plant growth [7]. Chicken manure compost (CM) is also fine-textured and is cheaper than VC. Properly treated CM could have nutrients readily available to plants $[33,34]$.

Most research testing the effect of $\mathrm{BC}$ in germination substrates usually choses to use $\mathrm{BC}$ to substitute certain percentages of the commercial propagation mix. There is limited research testing propagation substrate with $\mathrm{BC}$ and composts instead of commercial propagation mix. More research is needed to find mixes with $B C$, especially at high percentages, on seed germination with comparable results to commercial germination mix.

Due to previous success of using the mixed hardwood BC in container production trials, the objective of this study was to evaluate the mixes of high percentages ( $70 \%$ or $80 \%$, by volume) of the mixed hardwood $\mathrm{BC}$ with the rest being composts (VC or $\mathrm{CM}$ ) on seed germination and seedling growth, compared to a commercial seed propagation mix (the control).

\section{Materials and Methods}

\subsection{Germination Substrate Selection and Characterization}

The BC used in this study was a byproduct of the fast pyrolysis of mixed hardwood (Proton Power, Inc., Lenior City, TN, USA). The nutrient analysis (N, P, K, Ca, Mg, S, B, Ca, Cu, Fe, Mn, Na, 
and $\mathrm{Zn}$ ) of the BC was tested by the Texas A\&M AgriLife Extension Service Soil, Water, and Forage Testing Laboratory in College Station, TX, USA and is shown in Table 1. The total $\mathrm{N}$ was determined spectrophotometrically by a combustion process [35] and the minerals (including $\mathrm{P}, \mathrm{K}, \mathrm{Ca}, \mathrm{Mg}, \mathrm{S}, \mathrm{B}$, $\mathrm{Ca}, \mathrm{Cu}, \mathrm{Fe}, \mathrm{Mn}, \mathrm{Na}$, and $\mathrm{Zn}$ ) were determined by inductively coupled plasma analysis of a nitric acid digest [36]. Two composts, including VC (Pachamama Earthworm Castings; Lady Bug Brand, Conroe, TX, USA) and CM (Back to Nature, Inc., Slaton, TX, USA), were chosen to mix with the BC. A commercial propagation mix (Propagation Mix; Sun Gro Inc., Agawam, MA, USA) was used as the control to germinate seeds. The $\mathrm{pHs}$ of the $\mathrm{BC}, \mathrm{VC}$, and $\mathrm{CM}$ were measured using a handheld pH-EC meter (HI 98129, Hanna Instruments, Woonsocket, RI, USA) and electrical conductivity (EC) was measured using the Bluelab Combo Meter (Bluelab Corporation Limited, Tauranga, New Zealand) according to the pour-through extraction method using the same amount of leachate for each test [37]. The pHs of the BC, VC, and CM were 11.18, 4.8, and 7.5, respectively. The ECs of the BC, VC, and $\mathrm{CM}$ were 2.0, 6.7, and $32.9 \mathrm{dS} \mathrm{m}^{-1}$, respectively. The physical properties of the $\mathrm{BC}, \mathrm{VC}$, and $\mathrm{CM}$ were reported previously by Huang et al. [26]. Physical properties, including the total porosity (the percent of pores in a substrate), container capacity (the maximum percent volume a substrate can hold water), air space (the percent of pores filled with air after drainage), and bulk density (the ratio of dry weight to the volume of the substrate) were determined using the North Carolina State University Horticultural Substrates Laboratory porometers [38]. Six replications were tested to determine the physical properties. The total porosities of the BC, VC, and CM were $84.7 \%, 75.0 \%$, and $64.4 \%$, respectively. The container capacities of the BC, VC, and CM were $60.3 \%, 72.2 \%$, and $60.0 \%$, respectively. The air spaces of the BC, $\mathrm{VC}$, and $\mathrm{CM}$ were $24.4 \%, 2.8 \%$, and $4.4 \%$, respectively. The bulk densities of the $\mathrm{BC}$, VC, and CM were $0.15,0.38$, and $0.62 \mathrm{~g} \mathrm{~cm}^{-3}$, respectively.

Table 1. Nutrient analysis of the biochar used in the experiments.

\begin{tabular}{cccccccccccc}
\hline $\mathbf{N}$ & $\mathbf{P}$ & $\mathbf{K}$ & $\mathbf{C a}$ & $\mathbf{M g}$ & $\mathbf{S}$ & $\mathbf{F e}$ & $\mathbf{B}$ & $\mathbf{C u}$ & $\mathbf{M n}$ & $\mathbf{N a}$ & $\mathrm{Zn}$ \\
\hline $\mathbf{( \% )}$ & & & & \multicolumn{7}{c}{$\mathbf{( m g ~ k g}^{-\mathbf{1})}$} \\
\hline 0.23 & 456 & 6362 & 27,507 & 1299 & 231 & 2039 & 15 & 9 & 905 & 107 & 13 \\
\hline
\end{tabular}

\subsection{Experimental Design and Setup}

Three experiments were conducted to test the effect of mixes with the BC-compost (VC or CM) on seed germination and seedling growth. Each treatment in the three experiments was replicated 4 times and arranged in a completely randomized design in the greenhouse located on Texas A\&M University campus, College Station, TX, USA. Six seeds were sown for each replication with one seed per cell (hexagon with side length of $2.6 \mathrm{~cm}$; height: $4.2 \mathrm{~cm}$; volume: $20 \mathrm{~cm}^{3}$ ). The average greenhouse temperature, relative humidity, and dew point for Experiment 1 were approximately $22.4{ }^{\circ} \mathrm{C}, 46.7 \%$, and $8.7^{\circ} \mathrm{C}$, respectively. The average greenhouse temperature, relative humidity, and dew point for Experiments 2 and 3 were approximately $27.1^{\circ} \mathrm{C}, 92.4 \%$, and $25.6^{\circ} \mathrm{C}$, respectively.

\subsubsection{Experiment 1}

Both Experiment 1 and 2 evaluated the potential of mixes of the mixed hardwood BC ( $70 \%$ or $80 \%$ by volume) with the rest being VC to substitute the commercial seed propagation mix (the control) on different seeds but were conducted at different times. In Experiment 1, seven types of flower and vegetable seeds, from Morgan County Seeds (Barnett, MO, USA; tomato Solanum lycopersicum, okra Abelmoschus esculentus), Ball Horticultural Company (West Chicago, IL, USA; celosia Celosia plumosa, vinca Catharanthus roseus 'Vitalia Pink,' marigold Tagetes patula), Plantation Products LLC. (Norton, MA, USA; zinnia Zinnia elegans), and Johnny's Selected Seeds (Winslow, ME, USA; basil Ocimum basilicum), were sown on 14 October 2016 and observed for 2 weeks. Four types of seeds from Botanical Interests (Broomfield, CO, USA), including radish (Raphanus sativus) and three relatively bigger seeds (cowpea 
Vigna unguiculata, corn Zea mays var. rugosa, pumpkin Cucurbita pepo) were sown on 21 October 2016 and observed for 10 days.

\subsubsection{Experiment 2}

Experiment 2 was conducted with the same treatments in Experiment 1: 7BC:3VC and 8BC:2VC (by volume) to compare with the commercial propagation mix (the control). During germination test, six types of flower seeds, from Floranova Ltd. (Pierceton, IN, USA; salvia Salvia splendens 'Sizzler Red,' petunia Petunia 'Espresso Sweet Pink'), Ball Horticultural Company (West Chicago, IL, USA; marigold Tagetes patula, vinca Catharanthus roseus 'Vitalia Pink'), and PanAmerican Seed Co. (West Chicago, IL, USA; zinnia Zinnia angustifolia, coleus Solenostemon scutellarioides 'Wizard Golden'), were sown on 17 May 2017 and observed for 20 days. Five types of seeds, from Producers Cooperative Association (Bryan, TX, USA; corn Zea mays 'Bodacious') and Botanical Interests (Broomfield, CO, USA; cowpea Vigna unguiculata, edamame Glycine max ‘Butterbean,' pumpkin Cucurbita pepo, radish Raphanus sativus), were sown on 17 May 2017 and observed for 16 days.

\subsubsection{Experiment 3}

The $\mathrm{BC}$ was mixed with $\mathrm{CM}$ at the ratio of $7 \mathrm{BC}: 3 \mathrm{CM}$ and $8 \mathrm{BC}: 2 \mathrm{CM}$ (by volume) to compare with the commercial propagation mix (the control). Experiment 3 was conducted on 22 April 2017. During the germination test, twelve types of seeds, from Producers Cooperative Association (Bryan, TX, USA; watermelon Citrullus lanatus 'Black Diamond,' corn Zea mays 'Bodacious'), Botanical Interests (Broomfield, CO, USA; pumpkin Cucurbita pepo, edamame Glycine max 'Butterbean,' cowpea Vigna unguiculata, radish Raphanus sativus), Floranova Ltd. (Pierceton, IN, USA; salvia Salvia splendens 'Sizzler Red,' petunia Petunia x hybrida F1 'Espresso Sweet Pink'), Ball Horticultural Company (West Chicago, IL, USA; marigold Tagetes patula, vinca Catharanthus roseus 'Vitalia Pink'), and PanAmerican Seed Co. (West Chicago, IL, USA; zinnia Zinnia angustifolia, coleus Solenostemon scutellarioides 'Wizard Golden'), were sown and observed for 20 days.

\subsection{Measurements}

For Experiment 1, 2, and 3, the number of seed germinations was monitored every day. Seeds were counted as germinated when two cotyledons were visible. The emergence percentage (EP) and emergence index (EI) were calculated to reflect the overall germination rate and germination speed, respectively.

Emergence percentage was calculated using the following formula:

$$
\mathrm{EP}=\left(\frac{\text { No.of emerged seedlings }}{\text { Total No.of seeds }}\right) \times 100 \%
$$

Emergence index was calculated as:

$$
\mathrm{EI}=\sum_{i=1}^{n}\left(\frac{\mathrm{EP} i}{\mathrm{~T} i}\right)
$$

where $\mathrm{EP}_{i}$ is $\mathrm{EP}$ on day $i$, and $\mathrm{T}_{i}$ is the number of days after sowing.

For Experiments 1 and 3, at the end of the germination test, the seedlings in each replication were harvested from the medium surface to measure the mean fresh weight (FW) of each seedling in each replication. For Experiment 2, after the germination test, one randomly-selected seedling from each replication was transplanted to a commercial growing mix (Professional growing mix; Sun Gro Inc., Agawam, MA, USA) in a 6-inch pot (depth: $10.8 \mathrm{~cm}$; top diameter: $15.5 \mathrm{~cm}$; bottom diameter: $11.3 \mathrm{~cm}$; volume: $1330 \mathrm{~cm}^{3}$ ) and randomly arranged in the greenhouse. The other remaining seedlings in each replication were harvested from the medium surface and the mean FW of each seedling in each replication measured. The transplanted plants were harvested after 7 weeks to test the effect of the 
mixes with the $\mathrm{BC}$ and VC on seedling growth. The dry weight (DW) of plants was measured after oven-dried at $80^{\circ} \mathrm{C}$ until constant weight.

\subsection{Statistical Analysis}

Data were analyzed with one-way analysis of variance (ANOVA) using JMP Statistical Software (version Pro 12.2.0; SAS Institute, Cary, NC, USA) to test the effect of different germination mix on seed germination and seedling growth. The type of germination mix was the main factor. Treatments with the $\mathrm{BC}$ and composts (either VC or $\mathrm{CM}$ ) were compared to the control (the commercial propagation mix) using Dunnett's test and means were separated when treatments were significant at $p<0.05$.

\section{Results and Discussion}

\subsection{The Effect of the Biochar and Compost Mix on Seed Germination Stage}

In Experiment 1, it was observed that all seeds in the BC and VC mixes had similar EPs to the control's except for cowpea and corn in the mix with 70\% BC and 30\% VC (by volume; 7BC:3VC) and pumpkin in both BC:VC mixes, which were lower than the control (Figure 1a). Celosia in 8BC:2VC and pumpkin in both $\mathrm{BC}: \mathrm{VC}$ mixes had lower EIs than the control's, with the other seeds having better or equal EIs (Figure 1b). In Experiment 2, it was observed that all seeds had similar EPs and EIs in both BC:VC mixes when compared to the control's (Figure 2). This indicated that all the seeds in both $\mathrm{BC}: \mathrm{VC}$ mixes had similar germination rates and speeds compared to the ones in the commercial propagation mix. Most of the results were similar in Experiments 1 and 2 except for the EP of cowpea, corn, and pumpkin and the EI of pumpkin. The different cultivars of the cowpea seeds could have led to different EPs. For corn and pumpkin, the different result could be due to the different batches of the seeds, temperatures of the days when conducting Experiments 1 and 2, and different amounts of water applied for germination.

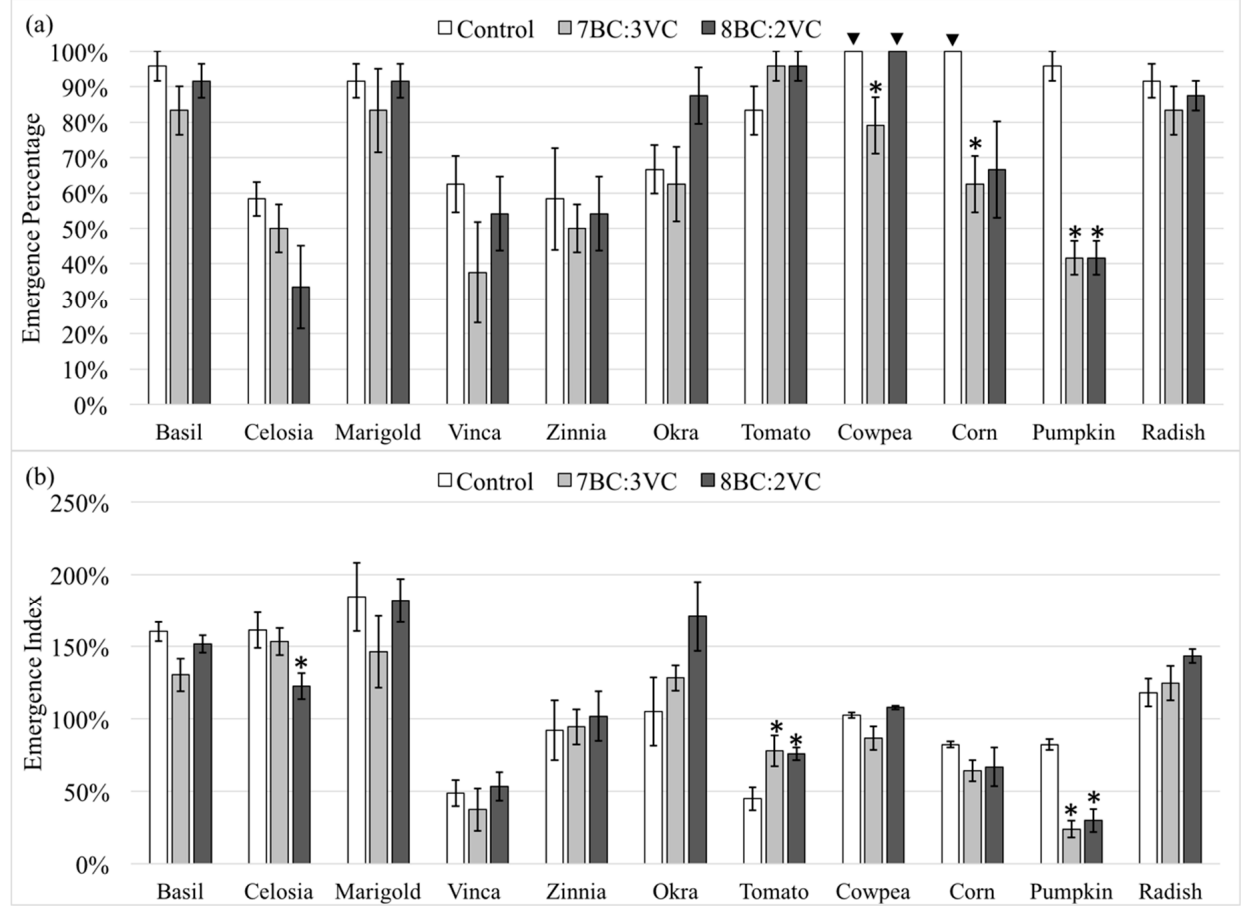

Figure 1. Seeds' emergence percentages (a) and emergence indexes (b) (mean \pm standard error) in commercial propagation mix (control), 70\% biochar:30\% vermicompost (7BC:3VC, by volume), or 8BC:2VC in Experiment 1. The asterisks $\left(^{*}\right)$ indicate differences from the control using Dunnett's test at $p<0.05(n=4)$. Means indicated by " $\mathbf{\nabla}$ " are $100 \% \pm 0$. 

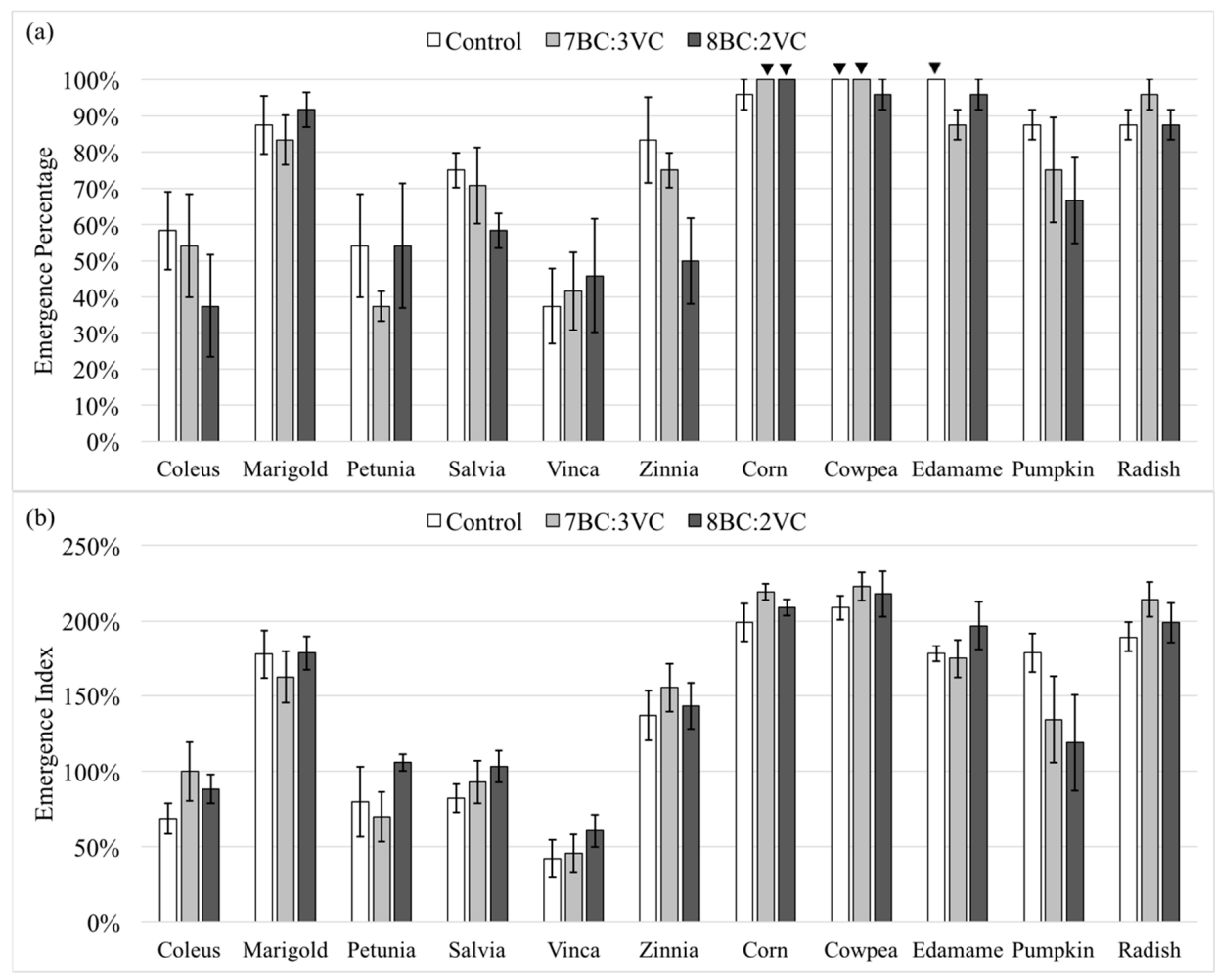

Figure 2. Seeds' emergence percentages (a) and emergence indexes (b) (mean \pm standard error) in commercial propagation mix (control), 70\% biochar:30\% vermicompost (7BC:3VC, by volume), or 8BC:2VC in Experiment 2. Means indicated by " $\mathbf{\nabla}$ " are $100 \% \pm 0$.

The results from Experiments 1 and 2 demonstrate that mixes of $70 \%$ or $80 \%$ (by volume) BC with the rest being VC have the potential to be substituted into the commercial seed propagation mixes for basil, coleus, edamame, marigold, okra, petunia, radish, salvia, tomato, vinca, and zinnia seeds with similar or higher EPs and EIs compared to the control's. Similar to our results, Nieto et al. [39] tested and indicated that the germination rate of the lettuce seeds in mixes with $75 \% \mathrm{BC}$ (from pruning waste at 300 or $500{ }^{\circ} \mathrm{C}$ ) and peat were similar to the $100 \%$ peat control. Margenot et al. [23] also showed that the substrate with $70 \%$ (by volume) softwood $\mathrm{BC}$ and $30 \%$ perlite without $\mathrm{pH}$ adjustment had no negative effect on the germination rate of marigold seeds compared to the 70:30 peat:perlite mixture. Webber III et al. [20] concluded that the percentage of seedling establishment for green beans (Phaseolus vulgaris var. 'Bowie') in mixes of $75 \%$ sugarcane bagasse BC or pine BC, with the rest being commercial growing media, was similar to that of the control. The reason for the lower EPs and EIs for cowpea, corn, and pumpkin seeds in Experiment 1 could be that these relatively bigger seeds do not have close contact with relatively big BC particles in the mixes. The uptake of the water, available from substrate particles in the case of container substrate, is required for the seeds to germinate [40].

In Experiment 3, all the seeds in mixes with the BC and CM had lower EPs than the ones in the control except for the edamame and watermelon seeds in $8 \mathrm{BC}: 2 \mathrm{CM}$, which were similar to the control (Figure 3). Similarly, the EIs of all the seeds in BC:CM mixes were lower than the ones in the control except for the edamame seeds in $8 \mathrm{BC}: 2 \mathrm{CM}$ and corn in both $\mathrm{BC}: \mathrm{CM}$ mixes. Therefore, all the seeds in either 7BC:3CM or 8BC:2CM mixes had lower EPs or EIs than those of the control, except for EI of corn. The reason for the suppressed seed germination could be the high $\mathrm{pH}$ of the germination mix ( $\mathrm{pH}$ of the BC: 11.18; $\mathrm{pH}$ of the CM: 7.5) and/or high EC $\left(32.9 \mathrm{dS} \mathrm{m}^{-1}\right.$ ) of the $\mathrm{CM}$, which led to salinity stress for the seeds. A similar result has been found in other research, which showed slow and poor germination of the seeds induced by a pig slurry compost due to the detrimental effect of high salinity [41]. Due to the addition of a high percentage of the mixed hardwood BC, the nutrient retention of the CM could be improved due to $B C^{\prime}$ s absorption ability and porous structure [42]. High 
$\mathrm{pH}$ or high salt stresses would suppress seed germination since the radicles are sensitive, with more deleterious effects under combined salt-alkaline stress [43]. Edamame and watermelon seeds may have higher tolerance, compared to the other seeds.

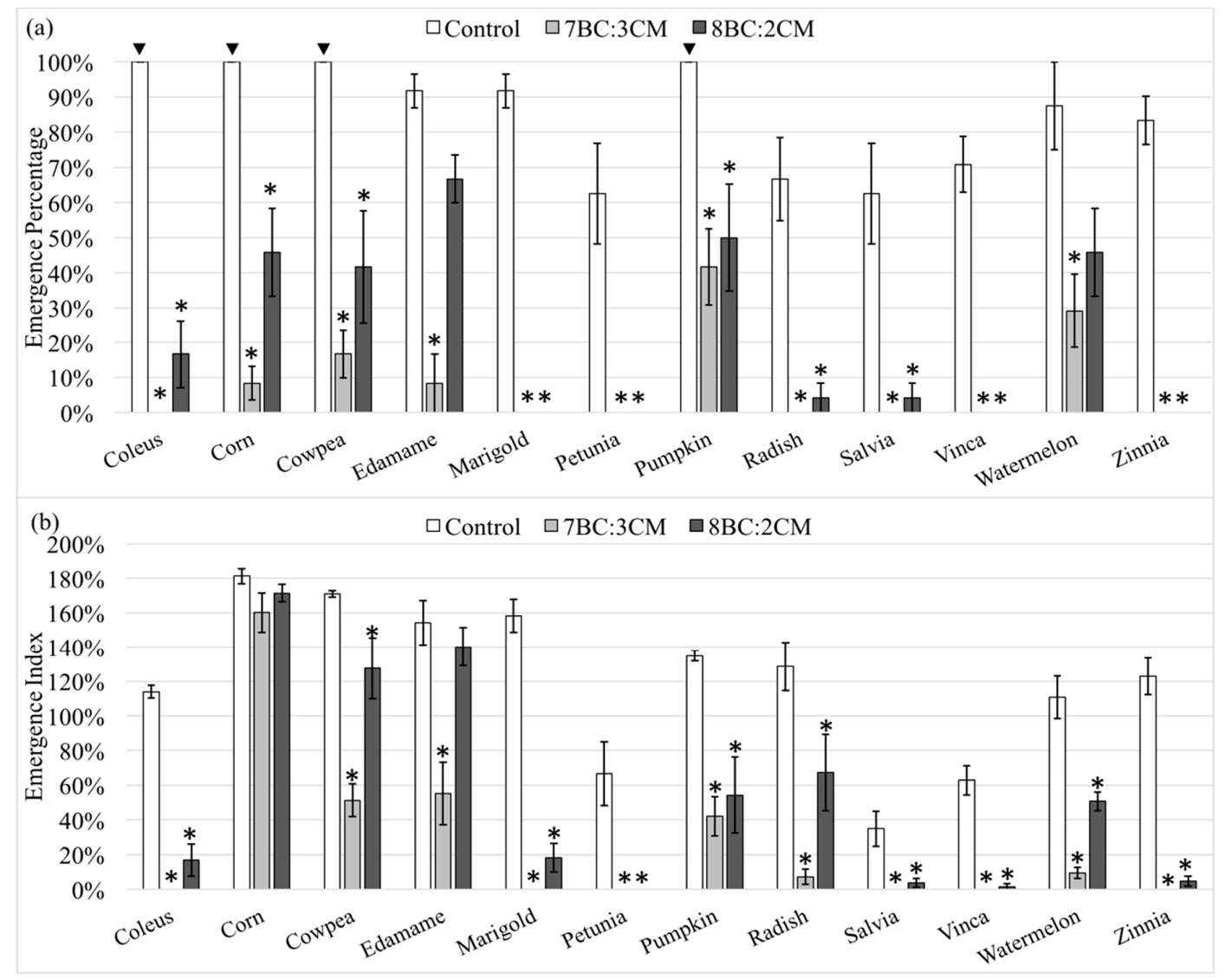

Figure 3. Seeds' emergence percentages (a) and emergence indexes (b) (mean \pm standard error) in commercial propagation mix (control), 70\% biochar:30\% chicken manure compost (7BC:3CM, by volume), or 8BC:2CM in Experiment 3. The asterisks $\left({ }^{*}\right)$ indicate differences from the control using Dunnett's test at $p<0.05(n=4)$. Means indicated by " $\nabla$ " are $100 \% \pm 0$.

\subsection{The Effects of the Biochar and Compost Mix on Seedling Growth}

In Experiment 1, the FWs of all the seedlings in the $\mathrm{BC}: \mathrm{VC}$ mixes were similar to the ones in the control except for the vinca and pumpkin seedlings in 7BC:3VC (Figure 4). Similarly, all harvested seedling FWs in BC:VC mixes in Experiment 2 were similar to control, except those of marigold and salvia in 8BC:2VC, which were lower than that of the control (Figure 5a). All plant DWs at 7 weeks after transplanting were similar to or higher than those of the controls (Figure $5 b$ ). Research has shown that the FWs and DWs of the squash (Cucurbita pepo var. 'Enterprise') seedlings in mixes of $75 \%$ (by volume) standard bagasse $\mathrm{BC}$ with the rest being commercial growing mix were similar to the ones in the control while those of the cantaloupe (Cucumis melo var. 'Magnum 45') seedlings were lower than the ones in the control [44]. Similarly, the FWs and DWs of green bean var. 'Bowie' seedlings in mixes of $75 \%$ (by volume) sugarcane bagasse $\mathrm{BC}$ or pine $\mathrm{BC}$ with the rest being commercial growing media were similar to the control [20]. Sáez et al. [41] also showed that mixes of $60 \%$ or $80 \%$ (by volume) holm oak BC (with the rest being pig slurry compost) had similar or higher shoot DWs compared to the mixes with $60 \%$ or $80 \%$ coir (the resting being pig slurry compost), respectively. 


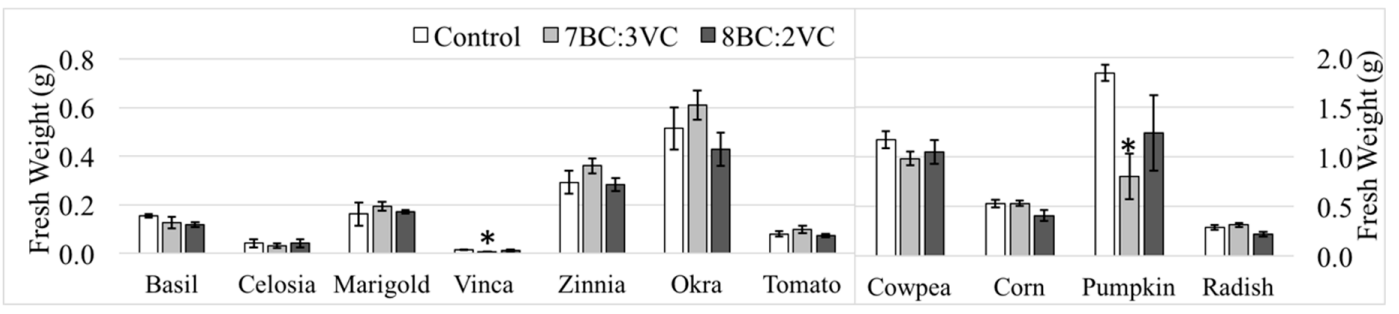

Figure 4. Fresh weight (mean \pm standard error) of the seedlings in commercial propagation mix (control), $70 \%$ biochar:30\% vermicompost (7BC:3VC, by volume), or 8BC:2VC in Experiment 1 . The asterisks indicate differences from the control using Dunnett's test at $p<0.05(n=4)$.
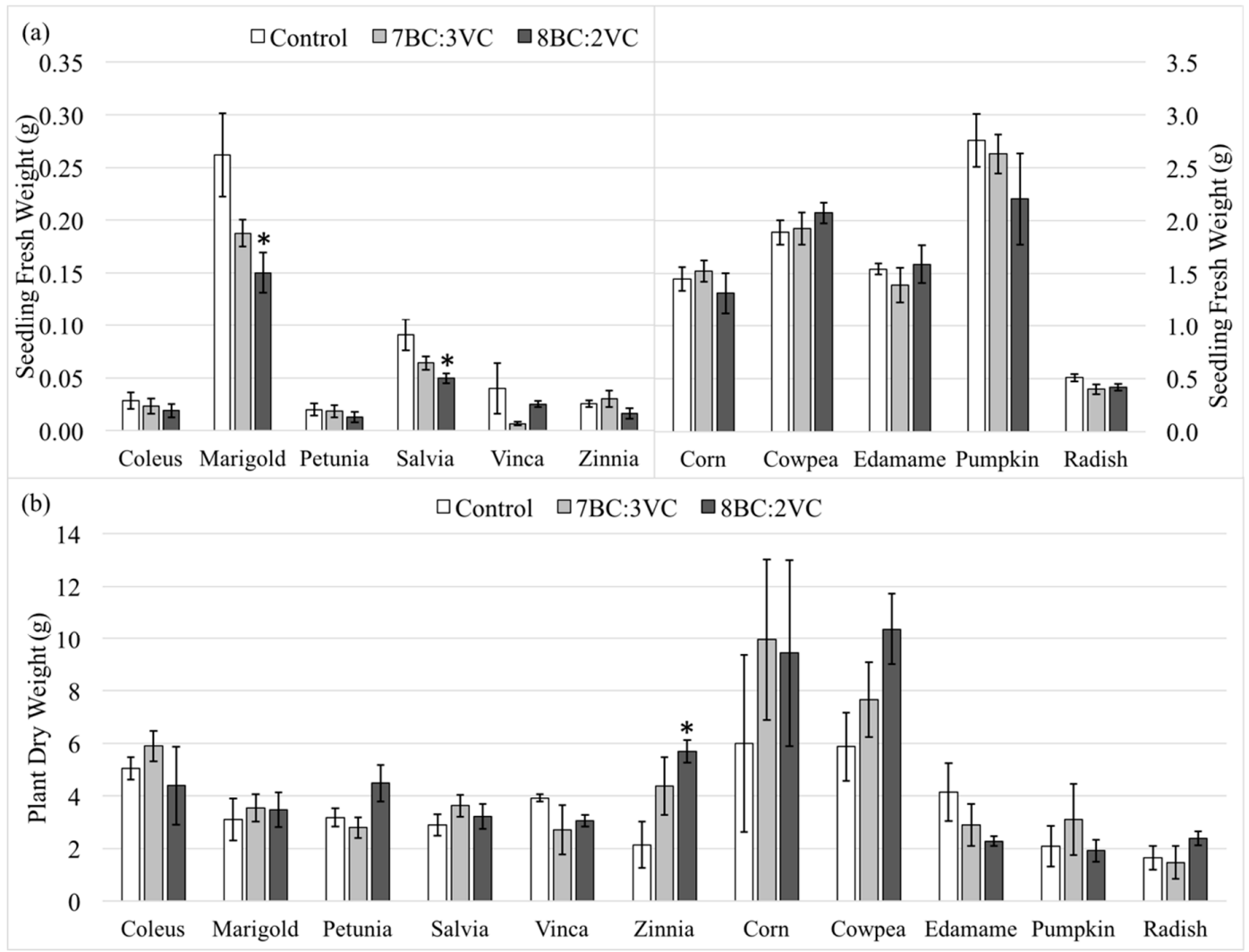

Figure 5. Fresh weights of the seedlings (a) and the dry weights of the plants harvested at 7 weeks after transplantation $(\mathbf{b})$ (mean \pm standard error), which were germinated in commercial propagation mix (control), 70\% biochar:30\% vermicompost (7BC:3VC, by volume), or 8BC:2VC in Experiment 2. The asterisks indicate differences from the control using Dunnett's test at $p<0.05(n=4)$.

In Experiment 3, similar to the results on EPs and EIs, the FWs of all the seedlings in the BC:CM mixes were lower than those in the control except for the edamame seedling in $8 \mathrm{BC}: 2 \mathrm{CM}$ and cowpea seedlings in both BC:CM mixes (Figure 6). The salinity and alkaline stresses caused by BC:CM mixes not only caused low and slow seed germination but also suppressed plant growth. The same $\mathrm{CM}$ and mixed hardwood $\mathrm{BC}$ has been used in the other research and the results also showed that the growth index, shoot DW and FW, and root and total DW of basil plants in mixes of the BC $(80 \%$ or $90 \%$, by volume) and $5 \% \mathrm{CM}$ with the rest being commercial growing mix were reduced due to high salt and high $\mathrm{pH}$ [26]. 


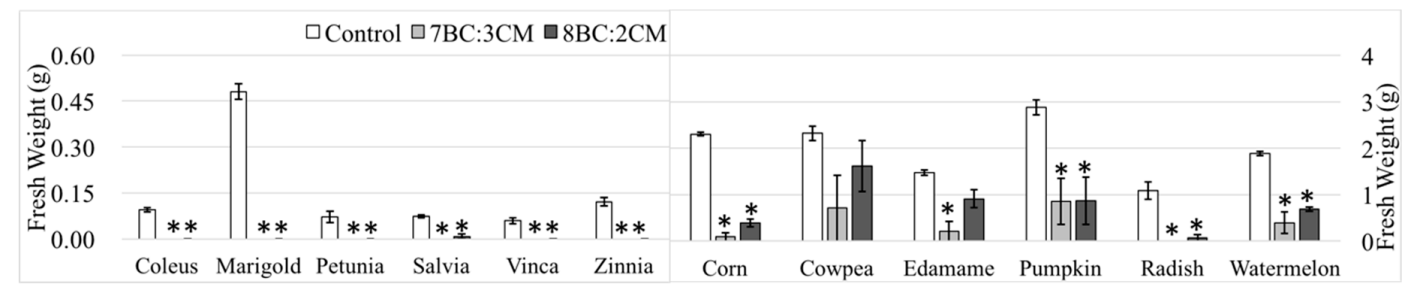

Figure 6. Fresh weights (mean \pm standard error) of the seedlings in commercial propagation mix (control), 70\% biochar:30\% chicken manure compost (7BC:3CM, by volume), or 8BC:2CM in Experiment 3. The asterisks indicate differences from the control using Dunnett's test at $p<0.05(n=4)$.

\section{Conclusions}

The results have shown that the high-percentage ( $70 \%$ or $80 \%$, by volume) $\mathrm{BC}$ mixes, with the rest being $\mathrm{VC}$, have the potential to be used as germination mixes to substitute the commercial peat-based seed propagation mix, while mixes with $70 \%$ or $80 \%$ (by volume) $\mathrm{BC}$, with the rest being $\mathrm{CM}$, are not recommended for seed germination or plant production. Basil, marigold, vinca, zinnia, okra, tomato, radish, coleus, petunia, salvia, and edamame seeds had similar or higher EPs and EIs in both BC:VC mixes compared to the control. The FWs of all the seedlings in the BC:VC mixes were similar to the ones in the control except for the vinca and pumpkin in 7BC:3VC in Experiment 1 and marigold and salvia in 8BC:2VC in Experiment 2. The DWs of all plants grown in both BC:VC mixes at 7 weeks after transplantation were similar to or higher than the control in Experiment 2. Due to the high $\mathrm{pHs}$ of the $\mathrm{BC}: \mathrm{CM}$ mixes and high salinity of $\mathrm{CM}$, all the seeds in either 7BC:3CM or $8 \mathrm{BC}: 2 \mathrm{CM}$ mixes had lower EPs or EIs than those of the controls, except for the EI of corn. The FWs of all the seedlings in the $\mathrm{BC}: \mathrm{CM}$ mixes were lower than those in the control except for the edamame in $8 \mathrm{BC}: 2 \mathrm{CM}$ and cowpea in both $\mathrm{BC}: \mathrm{CM}$ mixes. Therefore, $7 \mathrm{BC}: 3 \mathrm{VC}$ and $8 \mathrm{BC}: 2 \mathrm{VC}$ could be used as seed propagation mixes, while $7 \mathrm{BC}: 3 \mathrm{CM}$ or $8 \mathrm{BC}: 2 \mathrm{CM}$ are not recommended.

These results would be only suitable for these specific $\mathrm{BCs}$, VCs, and CMs, since different materials have different physical and chemical properties. More plant materials should be tested for the broader use of the BC:VC mixes for seed germination, or a small trial needs to be conducted before using such mixes in production.

Author Contributions: This review is a product of the combined effort of all the authors. M.G. conceived the experiments; L.H. conducted the experiment, analyzed the data, wrote the original draft, and improved it based on other authors' advice, mainly M.G.'s.; M.G. reviewed, edited, and revised the manuscript; P.Y. conducted some measurements of the parameters and reviewed the manuscript.

Funding: This research received no external funding.

Acknowledgments: The authors thank the Agriculture Women Excited to Share Opinions, Mentoring, and Experiences (AWESOME) faculty group of the College of Agriculture and Life Sciences at Texas A\&M University for assistance with editing the manuscript.

Conflicts of Interest: The authors declare no conflict of interest.

\section{References}

1. Bewley, J.D.; Bradford, K.; Hilhorst, H. Seeds: Physiology of Development, Germination and Dormancy, 3rd ed.; Springer: New York, NY, USA, 2012; p. 133.

2. Carlile, B.; Coules, A. Towards sustainability in growing media. Acta Hortic. 2013, 1013, 341-349. [CrossRef]

3. Leifeld, J.; Menichetti, L. The underappreciated potential of peatlands in global climate change mitigation strategies. Nat. Commun. 2018, 9, 1071. [CrossRef] [PubMed]

4. Landis, T.D.; Morgan, N. Growing Media Alternatives for Forest and Native Plant Nurseries. In National Proceedings: Forest and Conservation Nursery Associations, Missoula, MT, USA, $23-25$ June 2008; Dumroese, R.K., Riley, L.E., Eds.; USDA Forest Service, Rocky Mountain Research Station: Fort Collins, CO, USA, 2009; pp. 26-31. 
5. Jackson, B.E.; Wright, R.D.; Barnes, M.C. Pine tree substrate, nitrogen rate, particle size, and peat amendment affect poinsettia growth and substrate physical properties. HortScience 2008, 43, 2155-2161. [CrossRef]

6. Lehmann, J. A handful of carbon. Nature 2007, 447, 143-144. [CrossRef]

7. Liu, R.; Gu, M.; Huang, L.; Yu, F.; Jung, S.K.; Choi, H.S. Effect of pine wood biochar mixed with two types of compost on growth of bell pepper (Capsicum annuum L.). Hortic. Environ. Biotechnol. 2019, 60, 313-319. [CrossRef]

8. Cho, M.S.; Meng, L.; Song, J.H.; Han, S.H.; Bae, K.; Park, B.B. The effects of biochars on the growth of Zelkova serrata seedlings in a containerized seedling production system. Sci. Technol. 2017, 13, 25-30. [CrossRef]

9. Uzoma, K.; Inoue, M.; Andry, H.; Fujimaki, H.; Zahoor, A.; Nishihara, E. Effect of cow manure biochar on maize productivity under sandy soil condition. Soil Use Manag. 2011, 27, 205-212. [CrossRef]

10. Jin, Y.; Liang, X.; He, M.; Liu, Y.; Tian, G.; Shi, J. Manure biochar influence upon soil properties, phosphorus distribution and phosphatase activities: A microcosm incubation study. Chemosphere 2016, 142, 128-135. [CrossRef]

11. Lei, O.; Zhang, R. Effects of biochars derived from different feedstocks and pyrolysis temperatures on soil physical and hydraulic properties. J. Soils Sediments 2013, 13, 1561-1572. [CrossRef]

12. Woolf, D.; Amonette, J.E.; Street-Perrott, F.A.; Lehmann, J.; Joseph, S. Sustainable biochar to mitigate global climate change. Nat. Commun. 2010, 1, 56. [CrossRef]

13. Ippolito, J.A.; Laird, D.A.; Busscher, W.J. Environmental benefits of biochar. J. Environ. Q. 2012, 41, 967-972. [CrossRef] [PubMed]

14. Guo, Y.; Niu, G.; Starman, T.; Volder, A.; Gu, M. Poinsettia growth and development response to container root substrate with biochar. Horticulturae 2018, 4, 1. [CrossRef]

15. Guo, Y.; Niu, G.; Starman, T.; Gu, M. Growth and development of Easter lily in response to container substrate with biochar. J. Hortic. Sci. Biotechnol. 2018, 94, 80-86. [CrossRef]

16. Peng, D.; Gu, M.; Zhao, Y.; Yu, F.; Choi, H.S. Effects of biochar mixes with peat-moss based substrates on growth and development of horticultural crops. Hortic. Science Technol. 2018, 36, 501-512.

17. Choi, H.S.; Zhao, Y.; Dou, H.; Cai, X.; Gu, M.; Yu, F. Effects of biochar mixtures with pine-bark based substrates on growth and development of horticultural crops. Horti. Environ. Biotechnol. 2018, 59, 345-354. [CrossRef]

18. Huang, L.; Gu, M. Effects of biochar on container substrate properties and growth of plants-A review. Horticulturae 2019, 5, 14. [CrossRef]

19. Laird, D.A. The charcoal vision: A win-win-win scenario for simultaneously producing bioenergy, permanently sequestering carbon, while improving soil and water quality. Agron. J. 2008, 100, 178-181. [CrossRef]

20. Webber, C.L., III; White, P.M., Jr.; Gu, M.; Spaunhorst, D.J.; Lima, I.M.; Petrie, E.C. Sugarcane and pine biochar as amendments for greenhouse growing media for the production of bean (Phaseolus vulgaris L.) seedlings. J. Agric. Sci. 2018, 10, 58-68. [CrossRef]

21. Hoover, B.K. Herbaceous perennial seed germination and seedling growth in biochar-amended propagation substrates. HortScience 2018, 53, 236-241. [CrossRef]

22. Prasad, M.; Tzortzakis, N.; McDaniel, N. Chemical characterization of biochar and assessment of the nutrient dynamics by means of preliminary plant growth tests. J. Environ. Manag. 2018, 216, 89-95. [CrossRef]

23. Margenot, A.J.; Griffin, D.E.; Alves, B.S.; Rippner, D.A.; Li, C.; Parikh, S.J. Substitution of peat moss with softwood biochar for soil-free marigold growth. Ind. Crop. Prod. 2018, 112, 160-169. [CrossRef]

24. Fan, R.; Luo, J.; Yan, S.; Zhou, Y.; Zhang, Z. Effects of biochar and super absorbent polymer on substrate properties and water spinach growth. Pedosphere 2015, 25, 737-748. [CrossRef]

25. Gascó, G.; Cely, P.; Paz-Ferreiro, J.; Plaza, C.; Méndez, A. Relation between biochar properties and effects on seed germination and plant development. Biol. Agric. Hortic. 2016, 32, 237-247. [CrossRef]

26. Huang, L.; Niu, G.; Feagley, S.E.; Gu, M. Evaluation of a hardwood biochar and two composts mixes as replacements for a peat-based commercial substrate. Ind. Crop. Prod. 2019, 129, 549-560. [CrossRef]

27. Huang, L. Effects of Biochar and Composts on Substrates Properties and Container-Grown Basil (Ocimum basilicum) and Tomato (Solanum lycopersicum). Master's Thesis, Texas A\&M University, College Station, TX, USA, 2018. 
28. Lim, S.L.; Lee, L.H.; Wu, T.Y. Sustainability of using composting and vermicomposting technologies for organic solid waste biotransformation: Recent overview, greenhouse gases emissions and economic analysis. J. Clean. Prod. 2016, 111, 262-278. [CrossRef]

29. Chan, P.L.; Griffiths, D. The vermicomposting of pre-treated pig manure. Biol. Wastes 1988, $24,57-69$. [CrossRef]

30. Manna, M.; Jha, S.; Ghosh, P.; Ganguly, T.; Singh, K.; Takkar, P. Capacity of various food materials to support growth and reproduction of epigeic earthworms on vermicompost. J. Sustain. For. 2005, 20, 1-15. [CrossRef]

31. Atiyeh, R.; Subler, S.; Edwards, C.; Bachman, G.; Metzger, J.; Shuster, W. Effects of vermicomposts and composts on plant growth in horticultural container media and soil. Pedobiologia 2000,44,579-590. [CrossRef]

32. Sinha, R.K.; Agarwal, S.; Chauhan, K.; Valani, D. The wonders of earthworms \& its vermicompost in farm production: Charles darwin's friends of farmers, with potential to replace destructive chemical fertilizers. Agric. Sci. 2010, 1, 76.

33. Urra, J.; Alkorta, I.; Lanzén, A.; Mijangos, I.; Garbisu, C. The application of fresh and composted horse and chicken manure affects soil quality, microbial composition and antibiotic resistance. Appl. Soil Ecol. 2019, 135, 73-84. [CrossRef]

34. Chen, J.; Shi, L.; Liu, H.; Yang, J.; Guo, R.; Chen, D.; Jiang, X.; Liu, Y. Screening of fermentation starters for organic fertilizer composted from chicken manure. Asian Agric. Res. 2017, 9, 92-98.

35. Parkinson, J.; Allen, S. A wet oxidation procedure suitable for the determination of nitrogen and mineral nutrients in biological material. Commun. Soil Sci. Plant. Anal. 1975, 6, 1-11. [CrossRef]

36. Havlin, J.L.; Soltanpour, P. A nitric acid plant tissue digest method for use with inductively coupled plasma spectrometry. Commun. Soil Sci. Plant. Anal. 1980, 11, 969-980. [CrossRef]

37. LeBude, A.; Bilderback, T. The Pour-Through Extraction Procedure: A Nutrient Management Tool for Nursery Crops; AG-717-W: 2009; North Carolina Cooperative Extension: Raleigh, NC, USA, 2009.

38. Fonteno, W.; Hardin, C.; Brewster, J. Procedures for Determining Physical Properties of Horticultural Substrates Using the NCSU Porometer; Horticultural Substrates Laboratory, North Carolina State University: Raleigh, NC, USA, 1995.

39. Nieto, A.; Gascó, G.; Paz-Ferreiro, J.; Fernández, J.; Plaza, C.; Méndez, A. The effect of pruning waste and biochar addition on brown peat based growing media properties. Sci. Hortic. 2016, 199, 142-148. [CrossRef]

40. Manz, B.; Müller, K.; Kucera, B.; Volke, F.; Leubner-Metzger, G. Water uptake and distribution in germinating tobacco seeds investigated in vivo by nuclear magnetic resonance imaging. Plant. Physiol. 2005, 138, 1538-1551. [CrossRef] [PubMed]

41. Sáez, J.; Belda, R.; Bernal, M.; Fornes, F. Biochar improves agro-environmental aspects of pig slurry compost as a substrate for crops with energy and remediation uses. Ind. Crop. Prod. 2016, 94, 97-106. [CrossRef]

42. Laird, D.; Fleming, P.; Wang, B.; Horton, R.; Karlen, D. Biochar impact on nutrient leaching from a midwestern agricultural soil. Geoderma 2010, 158, 436-442. [CrossRef]

43. Li, R.; Shi, F.; Fukuda, K. Interactive effects of salt and alkali stresses on seed germination, germination recovery, and seedling growth of a halophyte Spartina alterniflora (Poaceae). S. Afr. J. Bot. 2010, 76, 380-387. [CrossRef]

44. Webber, C.L., III; White, P.M., Jr.; Spaunhorst, D.J.; Lima, I.M.; Petrie, E.C. Sugarcane biochar as an amendment for greenhouse growing media for the production of cucurbit seedlings. J. Agric. Sci. 2018, 10, 104. [CrossRef]

(C) 2019 by the authors. Licensee MDPI, Basel, Switzerland. This article is an open access article distributed under the terms and conditions of the Creative Commons Attribution (CC BY) license (http://creativecommons.org/licenses/by/4.0/). 